\title{
Seasonal microbiological quality of air in veterinary practices in Poland
}

\author{
Jolanta Sitkowska', Wiesław Sitkowski², Łukasz Sitkowski ${ }^{3}$, Krzysztof Lutnicki $^{4}$, Łukasz Adamek $^{2}$, \\ Piotr Wilkołek ${ }^{2}$ \\ ${ }^{1}$ Institute of Rural Health, Lublin, Poland \\ ${ }^{2}$ Sub-department of Clinical Diagnostics and Veterinary Dermatology, University of Life Sciences, Lublin, Poland \\ ${ }^{3}$ Department of English, Maria Curie-Skłodowska University, Lublin, Poland \\ ${ }^{4}$ Sub-department of Internal Diseases of Farm Animals and Horses, University of Life Sciences, Lublin, Poland
}

Sitkowska J, Sitkowski W, Sitkowski $Ł$, Lutnicki K, Adamek $Ł$, Wilkołek P. Seasonal microbiological quality of air in veterinary practices in Poland. Ann Agric Environ Med. 2015; 22(4): 614-624. doi: 10.5604/12321966.1185763

\begin{abstract}
Numerous studies focused on the bioaerosols in the areas of industry, agriculture and animal husbandry, concerning both residential and public buildings, have been conducted continuously for many years. The aim of the present work was to determine the concentration and composition of mesophilic bacterial flora in the air of selected medical and veterinary clinics located in the cities and in the countryside. Air sampling was carried out in 2011-2013 in 44 veterinary practices in autumn-winter and spring-summer seasons. The concentration of bacteria ranged from $39-5,034 \mathrm{cfu} / \mathrm{m}^{3}$, with higher values recorded in offices operating in the cities. In the examined medical and veterinary offices, Gram-positive bacteria comprised the largest group of microorganisms, among which Gram-positive cocci of the genus Staphylococcus prevailed, with the highest average of $1,074.40 \mathrm{cfu} / \mathrm{m}^{3}$ in urban offices during the autumn season. The smallest group was represented by Gram-negative bacteria, with a concentration of $0.0-215 \mathrm{cfu} / \mathrm{m}^{3}$. In total, $93 \mathrm{kinds} / \mathrm{species}$ of bacteria were identified. A 12-month series of studies showed the highest mean concentrations of microorganisms in autumn for offices located in the city, while the lowest in winter for rural centres. The environment of veterinary offices is a habitat of pathogenic and potentially pathogenic bacteria, which may pose health problems not only for residents, but also for the animals.
\end{abstract}

\section{Key words}

urban and rural veterinary clinics, bacterial aerosol, pathogenic bacteria, seasonal variability of microflora

\section{INTRODUCTION}

In recent years, an increasing number of veterinary practices have focused on the diagnosis and treatment of diseases affecting animals, predominantly dogs, cats and other small mammals, as well as reptiles, amphibians and exotic birds. Direct contact between veterinarians and diagnosed animals is associated with the risk of contamination. The veterinary staff come in contact with microorganisms present on the skin, mucous membrane or animal hair, and may also be exposed to other potentially infectious factors, including excreta and body fluids [1]. This poses the risk of contamination via the penetration of microorganisms through damaged skin, mucous membranes, and respiratory or digestive tracts [2, 3]. Veterinary clinics create a unique environment where the staff are often exposed to recognized and unrecognized microbial agents, many of which may be of animal origin or a component of the internal building environment and outdoor factors. The transmission of infectious agents requires three elements: the source of pathogens, host susceptibility and the way of transmission. The spread of microorganisms occurs through contact, aerosol and vector organisms (fleas, ticks, which pets can carry) [4]. Bioaerosols are ubiquitous air polluting agents in indoor spaces. They are a complex of dead or living microorganisms, pathogenic or non-pathogenic, cell fragments, spores, products of microorganisms metabolism and parts of plant or animal origin $[5,6]$. The exposure

Address for correspondence: Jolanta Sitkowska, Institute of Rural Health, Jaczewskiego 2, 20-090 Lublin, Poland

E-mail: jolasitkowska@tlen.pl

Received: 17 December 2013; accepted: 28 May 2014 to biological aerosols indoors is identified as a significant health threat, causing a number of infectious diseases, acute toxic reactions and allergies. Veterinarians, but also farmers, health care professionals and food industry workers, are the groups at high risk regarding diseases associated with the presence of microorganisms in the work environment $[5,7,8,9]$. Veterinary clinics, like any other 'enclosed' spaces, are reservoirs of microbiological agents: viruses, bacteria and fungi, the components of bioaerosols, which pose the most common threats,. The main sources of microorganism contamination in veterinary practice are not only animals, but also people, and the components of the indoor environment (walls, floors, equipment) and outdoor air (atmospheric). Exposure to bioaerosols is also a result of the clinic's location (the building itself may also be a reservoir of microorganisms), as well as the specific nature and scope of its activities and seasons [10, 11, 12, 13]. Furthermore, when assessing the degree of veterinary staff's exposure to microbiological agents, one should take into account additional factors, such as species diversity, the type of health problems in treated animals and the frequency of contact [14]. Employees involved in the handling of animals on livestock farms (barns, piggeries, poultry farms, stables) and veterinarians are usually exposed to high levels of bioaerosols, which have been the topic of various studies for many years $[15,16,17,18,19,20,21]$. In scientific literature, there is a lack of researches on the microbiological quality of air in veterinary practices. The presented study aims to address this issue and to assess the professional risks of veterinary surgeons in their workplace. 


\section{OBJECTIVE}

The aim of the study was to evaluate the microbiological quality of air in diagnostic and therapeutic veterinary facilities located in cities and rural regions, and to analyze the bacteria concentrations in all seasons.

\section{MATERIALS AND METHOD}

The study was conducted in 44 medical and veterinary surgeries in the period of 2011-2013. The clinics were located in urban and rural provinces of Lubelskie and Świętokrzyskie provinces of Poland, mostly run by individual farmers. Sampling was carried out in autumn (September, October, November), winter (December, January, February), spring (April, May) and summer (June and August). A total of 27 clinics were examined in autumn, 16 of which were urban and 11 rural. In winter, sampling was conducted in 17 veterinary clinics - 10 urban and 7 rural. Tests carried out in the last year of the study in spring and summer focused on 26 practices located in the city examined earlier during autumn and winter. The samples were collected during admissions hours, with doors and windows closed, safe from any air currents. Air conditioning equipment was not installed in the surveyed areas. Sampling was carried out with the use of Koch's free sedimentation method, which requires open Petri dishes with appropriate culture media to be left (for 30 minutes) in 3 different positions places in each tested room: slightly above floor level, at the procedure table and at eye-level. The plates containing a blood agar (tryptic soy agar (TSA) medium with 5\% defibrinated sheep blood), for the isolation and identification of mesophilic Gram-positive and Gram-negative bacteria, differentialselective EMB substrate with methylene blue and eosin for identification of Gram-negative bacteria and Chapman agar for isolation of mannitol-positive and mannitol-negative staphylococci, were used. After incubation at $37^{\circ} \mathrm{C}$ (for one day), at room temperature $20-22^{\circ} \mathrm{C}$ (for 2 days) and at $4{ }^{\circ} \mathrm{C}$ (for 3 days), macro-and microscopic evaluation of grown microorganisms was carried out, morphological types were assessed, and the identification of the most abundant colonies was performed using biochemical tests: Mikrolatest for Gram-negative rods and Gram-positive cocci (Erba Lachema s.r.o., Brno, Czech Republic) and GP2 MicroPlate $^{\mathrm{Tm}}$ test for Gram-positive rods (Biolog, Inc., Hayward, CA, USA). The number of bacteria grown on these media at various levels of sampling was summed and averaged. The concentrations of microorganisms in $1 \mathrm{~m}^{3}$ of air was determined as colony forming units $\left(\mathrm{cfu} / \mathrm{m}^{3}\right)$ using Omelianski's formula (Polish Standard PN-89/Z-04111/02).

$$
\mathrm{X}=\frac{\mathrm{A} \times 10000}{\mathrm{P} \times \mathrm{k}}
$$

$\mathrm{X}$ - number of microorganisms in air $\left(\mathrm{cfu} / \mathrm{m}^{3}\right)$

A - mean number of colonies on a plate

$\mathrm{P}$ - surface of a plate $\left(\mathrm{cm}^{2}\right)$

$\mathrm{k}$ - factor depending on the time of exposure ( $\mathrm{k}=1$ for 5 $\min , \mathrm{k}=2$ for $10 \mathrm{~min}, \mathrm{k}=3$ for $15 \mathrm{~min}, \mathrm{k}=6$ for $30 \mathrm{~min}$ ).

To assess the microbiological status of the air, different methods are used: sedimentation, collision and filter method, each of which has advantages and disadvantages.
The sedimentation method selected for this study, although displaced by measurements using standardized equipment, is still used and does not require any control instruments, and is cheap and recommended by Polish Standards PN$89 /$ Z-04008/08. In addition, it is considered to be one of the ways to evaluate surface contamination by microorganisms in the air [22]. Krogulski [22], having performed parallel measurements for comparative purposes under strictly controlled conditions (no air movement), obtained results which did not show significant differences between the total numbers of bacteria inside buildings determined with the use of aspiration and sedimentation methods.

Statistical analysis. Statistical significance of differences between the abundance of the isolated microorganisms was calculated with the rank test U Mann-Whitney. All calculations were performed for $\mathrm{p} \leq 0.05$ using Statistica v. 10.0 PL.

\section{RESULTS}

The study showed the presence of mesophilic Gram-positive bacteria in all veterinary offices. The total number of airborne bacteria isolated on TSA blood agar varied from 39 $5,034 \mathrm{cfu} / \mathrm{m}^{3}$. Average values $\left(\mathrm{cfu} / \mathrm{m}^{3}\right)$ of all microorganisms grown on the agar ranged from 226.9 in the offices located in the countryside to $2,121.80$ in urban practices during the winter and autumn seasons. The great majority of bacteria grown on blood agar (Gram-positive cocci, Grampositive rods, Gram-negative rods, bacilli and mesophilic actinomycetes), were most strongly represented in urban practices in autumn. Throughout the study period, a decrease in the number of Gram-positive cocci and Gram-positive rods in winter and spring was noted in these practices, and then an increase in number was reported in summer.

In the case of Bacillus spp. and mesophilic actinomycetes, a decrease in winter was followed by growth during the spring and summer. In rural centres, regardless of the season, mean values $\left(\mathrm{cfu} / \mathrm{m}^{3}\right)$ of all the identified microorganisms were significantly lower than those isolated in urban practices. The largest group consisted of Gram-positive cocci with the highest average of $1,074.40 \mathrm{cfu} / \mathrm{m}^{3}$ (for urban clinics in autumn) and the lowest of $102.84 \mathrm{cfu} / \mathrm{m}^{3}$ (for rural clinics in winter). Gram-positive rods were most abundant in summer $-705.73 \mathrm{cfu} / \mathrm{m}^{3}$ and autumn $-631.75 \mathrm{cfu} / \mathrm{m}^{3}$ in clinics located in the cities, and reached their lowest values in winter in rural clinics $-63.66 \mathrm{cfu} / \mathrm{m}^{3}$. Mean values for bacilli were at their peak in autumn $-347.71 \mathrm{cfu} / \mathrm{m}^{3}$ in urban veterinary care facilities, and the lowest in winter $-45.71 \mathrm{cfu} / \mathrm{m}^{3}$ in urban and $48.97 \mathrm{cfu} / \mathrm{m}^{3}$ in rural clinics. The smallest group of microorganisms were Gram-negative rods with mean values of $3.26 \mathrm{cfu} / \mathrm{m}^{3}$ in winter (countryside) to $39.18 \mathrm{cfu} / \mathrm{m}^{3}$ summer (city) and mesophilic actinomycetes $-8.16 \mathrm{cfu} / \mathrm{m}^{3}$ during winter in rural clinics and $3.26 \mathrm{cfu} / \mathrm{m}^{3}$ during winter in urban clinics. Comparison of the numerical averages of different groups of bacteria on blood agar given in $\mathrm{cfu} / \mathrm{m}^{3}$, as well as the percentage ratios, are shown in Table 1.

A statistically significant higher number of microorganisms isolated on blood agar was found in urban areas during summer, compared to the analogous period in rural areas for the following: Gram-positive cocci $(p=0.00005)$, Grampositive rods $(\mathrm{p}=0.00002)$ and Bacillus spp. $(\mathrm{p}=0.0002)$. 
Table 1. Mean $\mathrm{cfu} / \mathrm{m}^{3}$ values and the percentage of different organism groups isolated on blood agar at different seasons ( $\mathrm{N}=69$ )

\begin{tabular}{|c|c|c|c|c|c|c|c|c|}
\hline & & & $\begin{array}{c}\text { Blood agar - total } \\
\mathrm{cfu} / \mathrm{m}^{3}\end{array}$ & Gram-negative rods & Gram-positive cocci & Gram-positive rods & Bacillus spp. & $\begin{array}{c}\text { Mesophilic } \\
\text { actinomycetes }\end{array}$ \\
\hline A & UA & $\mathrm{x} \pm \mathrm{SD}$ & $2121.80 \pm 1311.31$ & $19.58 \pm 24.25$ & $1074.4 \pm 857.67$ & $631.75 \pm 506.71$ & $347.71 \pm 343.09$ & $48.35 \pm 50.38$ \\
\hline \multirow{2}{*}{ W } & \multirow{2}{*}{ UA } & $\mathrm{x} \pm \mathrm{SD}$ & $1288.06 \pm 1384.10$ & $22.85 \pm 16.46$ & $901.9 \pm 1160.77$ & $314.34 \pm 281.77$ & $45.71 \pm 49.19$ & $3.26 \pm 17.26$ \\
\hline & & $\%$ & & 1.77 & 70.02 & 24.41 & 3.55 & 0.25 \\
\hline $\mathrm{S}$ & UA & $\%$ & & 1.11 & 57.29 & 24.14 & 15.12 & 2.34 \\
\hline \multirow{2}{*}{ Su } & \multirow{2}{*}{ UA } & $\mathrm{x} \pm \mathrm{SD}$ & $1583.37 \pm 1030.05$ & $39.18 \pm 45.06$ & $740.49 \pm 537.7$ & $705.73 \pm 514.23$ & $61.22 \pm 34.36$ & $36.73 \pm 34.87$ \\
\hline & & $\%$ & & 2.41 & 46.46 & 43.68 & 5.06 & 2.39 \\
\hline \multirow{2}{*}{ A } & \multirow{2}{*}{ RA } & $\mathrm{x} \pm \mathrm{SD}$ & $499.53 \pm 545.28$ & $9.79 \pm 19.32$ & $257.34 \pm 359.56$ & $153.15 \pm 175.30$ & $59.66 \pm 115.25$ & $19.59 \pm 23.26$ \\
\hline & & $\%$ & & 1.96 & 51.52 & 30.66 & 11.94 & 3.92 \\
\hline \multirow{2}{*}{ W } & \multirow{2}{*}{ RA } & $\mathrm{x} \pm \mathrm{SD}$ & $226.9 \pm 1310.61$ & $3.26 \pm 16.52$ & $102.84 \pm 1077.48$ & $63.66 \pm 259.95$ & $48.97 \pm 42.60$ & $8.16 \pm 10.50$ \\
\hline & & $\%$ & & 1.57 & 69.50 & 21.89 & 6.09 & 0.95 \\
\hline
\end{tabular}

Commentary:

A- autumn $\quad$ UA-urban areas

W-winter RA-rural areas

S- spring N.d. - no detected

Su-summe

Similar calculations were made regarding the significance of differences between seasons for urban practices. It was noted that the number of Gram-negative rods during spring was significantly lower than during summer $(p=0.01)$ and autumn ( $\mathrm{p}=0.04)$. The number of Gram-positive rods reached its lowest value in spring and was significantly different from the numbers isolated during autumn $(\mathrm{p}=0.008)$, winter $(\mathrm{p}=0.008)$ and summer $(\mathrm{p}=0.01)$.

Among the identified Gram-positive cocci, Staphylococcus spp. was most abundant with an average of $53.87 \mathrm{cfu} / \mathrm{m}^{3}$ (for rural clinics in winter) - $732.19 \mathrm{cfu} / \mathrm{m}^{3}$ (urban offices in autumn) (Tab. 2).

The identified Gram-positive rods were best represented by the species found in urban offices: Microbacterium imperiale $-656.28 \mathrm{cfu} / \mathrm{m}^{3}$ (autumn), Microbacterium esteroaromaticum - $587.71 \mathrm{cfu} / \mathrm{m}^{3}$ (autumn), Microbacterium saperdae $543.63 \mathrm{cfu} / \mathrm{m}^{3}$ (summer), Microbacterium laevaniformans - $479.96 \mathrm{cfu} / \mathrm{m}^{3}$ (winter), Corynebacterium afermentans ss afermentans (CDC.A NF-1) - $465.27 \mathrm{cfu} / \mathrm{m}^{3}$ (autumn), Brevibacterium epidermidis - $382.01 \mathrm{cfu} / \mathrm{m}^{3}$ (summer). The concentration and percentage of all isolated types/species of Gram-positive rods are shown in Table 3. Offices with species/kinds of bacteria isolated on blood agar are listed in Table 4.

Gram-negative rods occurred in $66 \%$ of examined veterinary clinics. In all of the tested positions, 13 species of Gram-negative rods were found. Stenotrophomonas maltophilia was the most commonly isolated bacterium, observed in 9 practices, mainly in autumn and summer. The smallest species diversity in a group of Gram-negative rods was found in health-care centres located in the countryside during the winter season, and in the cities in the spring season. The summary of data concerning the concentration and percentage Gram-negative rods is shown in Table 5. Offices with Gram-negative rods isolated on EMB agar are listed in Table 6.

Staphylococcus xylosus and S. haemolyticus were the most frequently identified species among the mannitol-positive cocci grown on Chapman agar. Both species reached the highest mean values $\left(\mathrm{cfu} / \mathrm{m}^{3}\right)$, respectively: 70.20 in winter and 63.67 in summer. Potentially pathogenic strains of Staphylococcus aureus were found in amounts ranging from

Table 2. Mean cfu/ $\mathrm{m}^{3}$ values and the percentage of $\mathrm{Gram}$-positive cocci isolated on blood agar ( $\mathrm{N}=69$ )

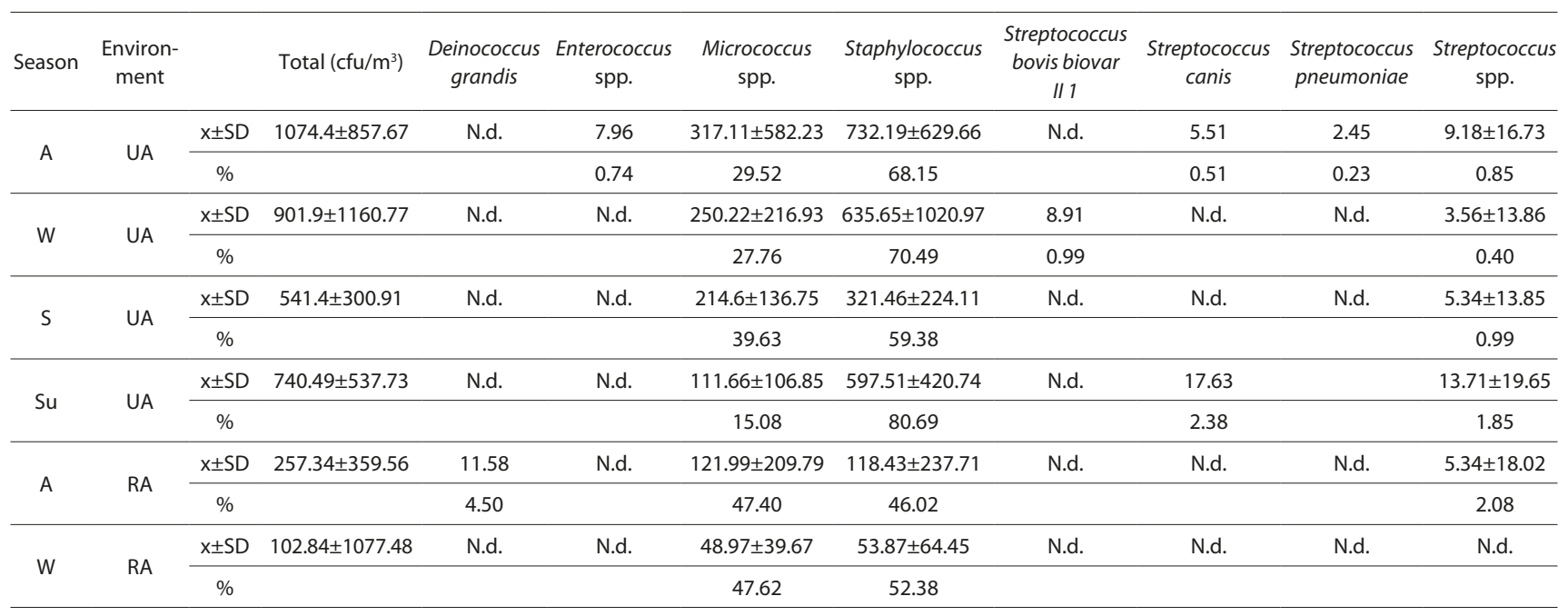

Commentary: like a Table 1 


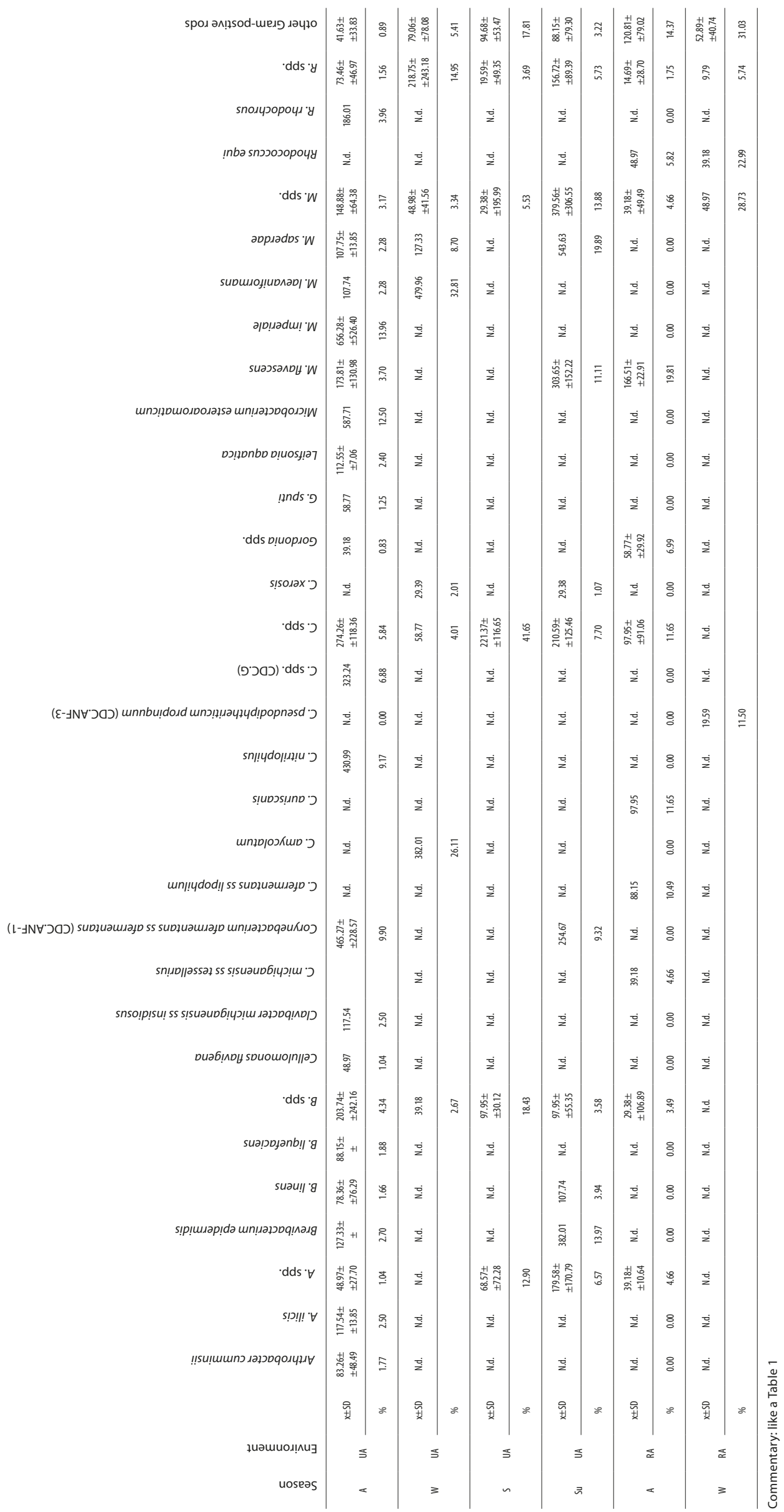


Table 4. The comparison of offices (1-44) where individual bacteria species isolated at different seasons were found

\begin{tabular}{|c|c|c|c|c|c|c|}
\hline \multirow[t]{2}{*}{ Species } & \multicolumn{4}{|c|}{ Urban areas } & \multicolumn{2}{|c|}{ Rural areas } \\
\hline & Autumn & Summer & Spring & Winter & Autumn & Winter \\
\hline Gram-negative rods & $\begin{array}{c}2,4,6,13,17,18 \\
20,21,37\end{array}$ & $\begin{array}{c}1,2,3,5,6,7,8,9 \\
10,11\end{array}$ & $2,4,5,8$ & $\begin{array}{c}1,2,3,4,32,31 \\
34,36,41\end{array}$ & $7,11,14,16$ & 30,38 \\
\hline Deinococcus grandis & & & & & 11 & \\
\hline Streptococcus pneumoniae & 21 & & & & & \\
\hline Streptococcus bovis biovar Il 1 & & & & 32 & & \\
\hline Enterococcus spp. & 24 & & & & & \\
\hline Micrococcus spp. & $\begin{array}{c}2,3,4,6,13,15 \\
17,18,20,21,22 \\
23,24,37\end{array}$ & $\begin{array}{l}1,2,5,7,8,9 \\
\quad 10,11\end{array}$ & $\begin{array}{c}1,2,3,4,5,6,7,8 \\
9,10,11\end{array}$ & $\begin{array}{c}1,2,3,4,32,34 \\
35,36\end{array}$ & $\begin{array}{l}8,9,11,12,14 \\
16,19,25,26\end{array}$ & $\begin{array}{l}28,29,30,38 \\
39,40\end{array}$ \\
\hline Staphylococcus spp. & $\begin{array}{c}2,3,4,6,13,15 \\
17,18,20,21,22 \\
23,24,37\end{array}$ & $\begin{array}{l}1,2,5,7,8,9 \\
\quad 10,11\end{array}$ & $\begin{array}{c}1,2,3,4,5,6,7,8 \\
9,10,11\end{array}$ & $\begin{array}{c}1,2,3,4,32,34 \\
35,36\end{array}$ & $\begin{array}{c}7,8,9,10,11,14 \\
16,19,25,26\end{array}$ & $29,30,38,39,40$ \\
\hline Streptococcus canis & 6 & 7 & & & & \\
\hline Streptococcus spp. & $13,18,20,22$ & $2,5,8,9,10$ & $6,8,10$ & 1,4 & 16,26 & \\
\hline Arthrobacter cumminsii & 2,24 & & & & & \\
\hline Arthrobacter ilicis & 3,18 & & & & & \\
\hline Arthrobacter spp. & 5,13 & $1,6,9$ & 1 & & 16 & \\
\hline Brevibacterium epidermidis & 5 & 7 & & & & \\
\hline Brevibacterium linens & $5,13,17,18$ & 8 & & & & \\
\hline Brevibacterium liquefaciens & 15 & & & & & \\
\hline Brevibacterium spp. & $3,4,6,21,22$ & $1,2,6,10$ & 4 & 31 & $7,8,25$ & \\
\hline Cellulomonas flavigena & 21 & & & & & \\
\hline Clavibacter michiganensis ss insidiosus & 2 & & & & 12 & \\
\hline $\begin{array}{l}\text { Corynebacterium afermentans ss afermentans } \\
\text { (CDC.ANF-1) }\end{array}$ & 1,20 & 2 & & & 14 & \\
\hline Corynebacterium amycolatum & & & & 32 & & \\
\hline Corynebacterium auriscanis & & & & & 26 & \\
\hline Corynebacterium nitrilophilus & 3 & & & & & \\
\hline
\end{tabular}

Corynebacterium pseudodiphtheriticum

propinquum (CDC.ANF-3)

\begin{tabular}{|c|c|c|c|c|c|c|}
\hline Corynebacterium spp. (CDC.G) & 3 & & & & & \\
\hline Corynebacterium spp. & $1,5,6,13,17$ & $6,7,8,9,10$ & $1,3,4,8,9$ & 4 & $7,8,14$ & \\
\hline Corynebacterium xerosis & & 1 & & 1 & & \\
\hline Gordonia spp. & 6,17 & & & & 14 & \\
\hline Gordonia sputi & 5 & & & & & \\
\hline Leifsonia aquatica & 1,37 & & & & & \\
\hline Microbacterium esteroaromaticum & 1 & & & & & \\
\hline Microbacterium flavescens & $2,5,6,21$ & 2,8 & & & 16 & \\
\hline Microbacterium imperiale & 4,37 & & & & & \\
\hline Microbacterium laevaniformans & 21 & & & 36 & & \\
\hline Microbacterium saperdae & 5,24 & 7 & & 31 & & \\
\hline Microbacterium spp. & $3,4,5,17,18$ & $1,6,9,10$ & 1 & 4,32 & $7,8,14$ & 28 \\
\hline Rhodococcus equi & & & & & 26 & 28 \\
\hline Rhodococcus rhodochrous & 2 & & & & & \\
\hline Rhodococcus spp. & $3,6,13,21$ & $2,6,8,9$ & 1 & $31,32,36$ & 14,16 & 29 \\
\hline other Gram-positive rods & $\begin{array}{c}4,5,17,18,20 \\
21,22,23\end{array}$ & $\begin{array}{c}1,2,3,4,6,7,8 \\
10,11\end{array}$ & $\begin{array}{c}1,2,3,5,6,8,9 \\
10,11\end{array}$ & $\begin{array}{c}1,2,3,4,27,34 \\
35,41\end{array}$ & $\begin{array}{c}9,10,12,16 \\
19,25\end{array}$ & $29,30,38,39,40$ \\
\hline Bacillus spp. & $\begin{array}{c}2,3,4,6,13,15 \\
17,18,20,21,22 \\
23,24,37\end{array}$ & $\begin{array}{c}1,2,3,5,6,7,8,9 \\
10,11\end{array}$ & $\begin{array}{c}1,2,3,4,5,6,7,8 \\
9,10,11\end{array}$ & $\begin{array}{r}1,2,3,4,27,31 \\
32,34,35,36,41\end{array}$ & $\begin{array}{c}8,9,11,12,14 \\
16,19,25,26\end{array}$ & $\begin{array}{c}28,29,30,38 \\
39,40\end{array}$ \\
\hline Streptomyces albus & 3,37 & $2,6,10$ & 6,8 & 3,35 & 14 & 38 \\
\hline Streptomyces spp. & $\begin{array}{c}1,2,3,4,5,6,13 \\
17,20,21,22\end{array}$ & $3,5,7,8,9,10,11$ & $\begin{array}{c}1,2,4,5,6,9 \\
10,11\end{array}$ & $1,2,3,34,32$ & $\begin{array}{c}7,8,9,11,12 \\
14,19\end{array}$ & 28,39 \\
\hline
\end{tabular}




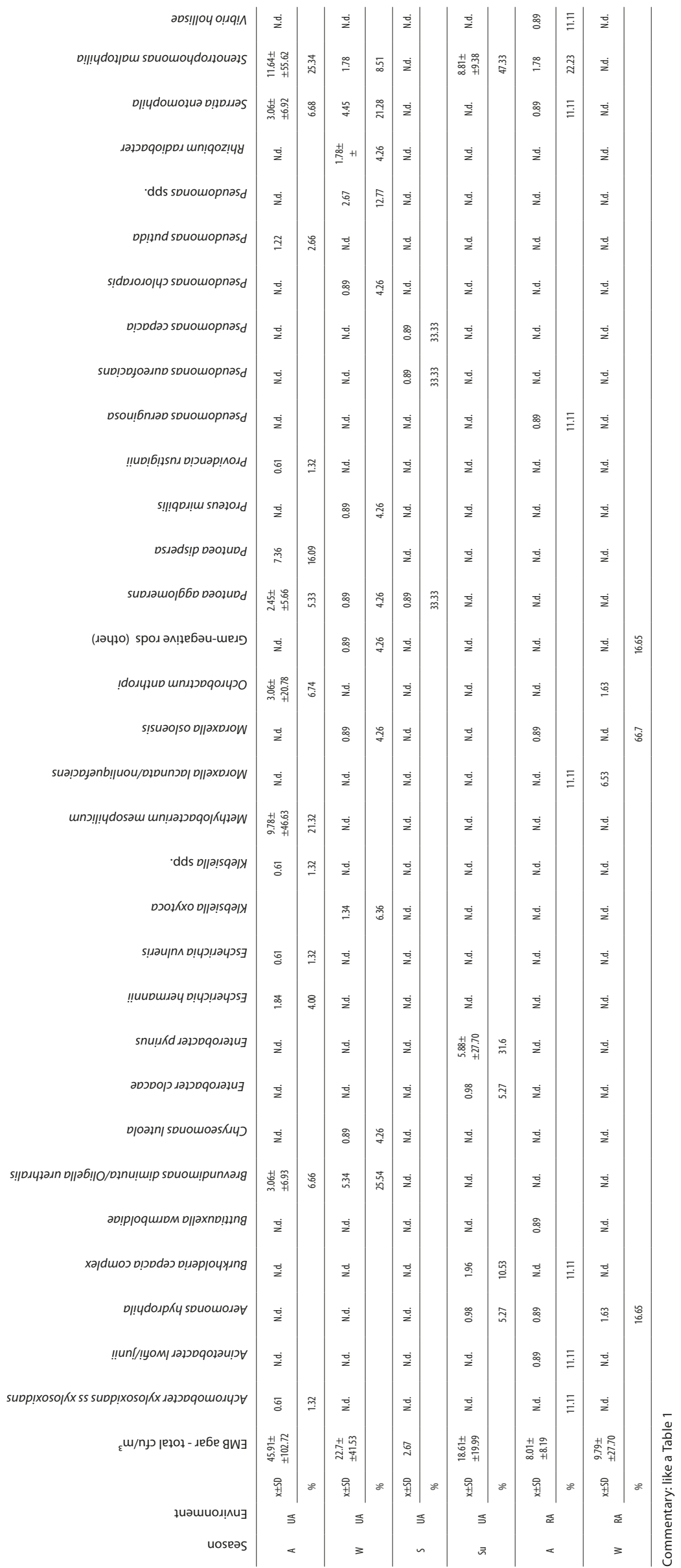


Table 6. The occurence of Gram-negative rods in the particular offices (1-44) across seasons

\begin{tabular}{|c|c|c|c|c|c|c|}
\hline \multirow{2}{*}{ Species } & \multicolumn{4}{|c|}{ Urban areas } & \multicolumn{2}{|c|}{ Rural areas } \\
\hline & Autumn & Summer & Spring & Winter & Autumn & Winter \\
\hline Achromobacter xylosoxidans ss xylosoxidans & 5 & N.d. & N.d. & N.d. & N.d. & N.d. \\
\hline Acinetobacter Iwofii/junii & N.d. & N.d. & N.d. & N.d. & 14 & N.d. \\
\hline Aeromonas hydrophila & N.d. & 11 & N.d. & N.d. & 14 & 30 \\
\hline Burkholderia cepacia complex & N.d. & 10 & N.d. & N.d. & N.d. & N.d. \\
\hline Buttiauxella warmboldiae & N.d. & N.d. & N.d. & N.d. & 16 & N.d. \\
\hline Brevundimonas diminuta/Oligella urethralis & 13,17 & N.d. & N.d. & 32 & N.d. & N.d. \\
\hline Chryseomonas luteola & N.d. & N.d. & N.d. & 3 & N.d. & N.d. \\
\hline Enterobacter cloacae & N.d. & 10 & N.d. & N.d. & N.d. & N.d. \\
\hline Enterobacter pyrinus & N.d. & 7,8 & N.d. & N.d. & N.d. & N.d. \\
\hline Escherichia hermannii & 4 & N.d. & N.d. & N.d. & N.d. & N.d. \\
\hline Escherichia vulneris & 6 & N.d. & N.d. & N.d. & N.d. & N.d. \\
\hline Klebsiella oxytoca & N.d. & N.d. & N.d. & 1 & N.d. & N.d. \\
\hline Klebsiella spp. & 22 & N.d. & N.d. & N.d. & N.d. & N.d. \\
\hline Methylobacterium mesophilicum & $17,20,22,37$ & N.d. & N.d. & N.d. & N.d. & N.d. \\
\hline Moraxella lacunata/nonliquefaciens & N.d. & N.d. & N.d. & N.d. & N.d. & 30 \\
\hline Moraxella osloensis & N.d. & N.d. & N.d. & 32 & 7 & N.d. \\
\hline Ochrobactrum anthropi & 5,6 & N.d. & N.d. & N.d. & N.d. & 38 \\
\hline other Gram-negative rods & N.d. & N.d. & N.d. & 41 & N.d. & N.d. \\
\hline Pantoea agglomerans & $1,2,4$ & N.d. & 5 & 3 & N.d. & N.d. \\
\hline Pantoea dispersa & 13 & N.d. & N.d. & N.d. & N.d. & N.d. \\
\hline Proteus mirabilis & N.d. & N.d. & N.d. & 32 & N.d. & N.d. \\
\hline Providencia rustigianii & 15 & N.d. & N.d. & N.d. & N.d. & N.d. \\
\hline Pseudomonas aeruginosa & N.d. & N.d. & N.d. & N.d. & 11 & N.d. \\
\hline Pseudomonas aureofacians & N.d. & N.d. & 4 & N.d. & N.d. & N.d. \\
\hline Pseudomonas cepacia & N.d. & N.d. & 1 & N.d. & N.d. & N.d. \\
\hline Pseudomonas chlororapis & N.d. & N.d. & N.d. & 3 & N.d. & N.d. \\
\hline Pseudomonas putida & 21 & N.d. & N.d. & N.d. & N.d. & N.d. \\
\hline Pseudomonas spp. & N.d. & N.d. & N.d. & 36 & N.d. & N.d. \\
\hline Rhizobium radiobacter & N.d. & N.d. & N.d. & 32,34 & N.d. & N.d. \\
\hline Serratia entomophila & 20,21 & N.d. & N.d. & 36 & 14 & N.d. \\
\hline Stenotrophomonas maltophilia & $18,20,21$ & $5,6,8,10$ & N.d. & 32 & 19 & N.d. \\
\hline Vibrio hollisae & N.d. & N.d. & N.d. & N.d. & 11 & N.d. \\
\hline
\end{tabular}

$0.89-47.75 \mathrm{cfu} / \mathrm{m}^{3}$ average values, peaking for urban offices during autumn. A comparison of $\mathrm{cfu} / \mathrm{m}^{3}$ average values, percentages, and the list of species at different positions on the Chapman medium are shown in Table 7. Offices with cocci isolated on Chapman agar are listed in Table 8.

\section{DISCUSSION}

At the present time, the issue of control over microbiological purity of the air is insufficiently developed in Polish legislature. Due to the lack of precise standards regarding air pollutants in veterinary clinics, the obtained results referred to the rooms of residential and non-industrial purposes [8]. According to suggestions made by Górny and Dutkiewicz [23], the acceptable concentration for mesophilic bacteria in these rooms is up to $5,000 \mathrm{cfu} / \mathrm{m}^{3}$. The average values identified in this study are placed in the range of $226.9 \mathrm{cfu} / \mathrm{m}^{3}$ $-2121.80 \mathrm{cfu} / \mathrm{m}^{3}$, thus, not exceeding the safety level. Neither in Poland nor worldwide has such research been conducted in case of veterinary clinics. Few available publications address the problem of microbiological quality of air in small animal veterinary clinics and pet stores $[24,25]$. The highest average concentration of microorganisms in pet stores in South Korea during winter was $2,037 \mathrm{cfu} / \mathrm{m}^{3}$, the lowest $301 \mathrm{cfu} / \mathrm{m}^{3}$, and in summer,respectively, 1,808 and $773 \mathrm{cfu} / \mathrm{m}^{3}$. Similar values have also been observed in animal clinics with the maximum and minimum average in winter at 3,604 and $234 \mathrm{cfu} / \mathrm{m}^{3}$, while in summer it was reported at 1,580 and $439 \mathrm{cfu} / \mathrm{m}^{3}[24,25]$. These results show similar values to those obtained in Polish veterinary clinics, with the highest levels reported during autumn in the cities $-2,121.80 \mathrm{cfu} / \mathrm{m}^{3}$ (the research in South Korea was not performed in autumn), and the lowest in winter in rural centers $-226.9 \mathrm{cfu} / \mathrm{m}^{3}$. Moreover, it was noted that the air-purifying devices installed in some pet stores and veterinary clinics had no effect on the quality of the air $[24,25]$. Regardless of the type of object, bioaerosol concentrations were significantly higher 


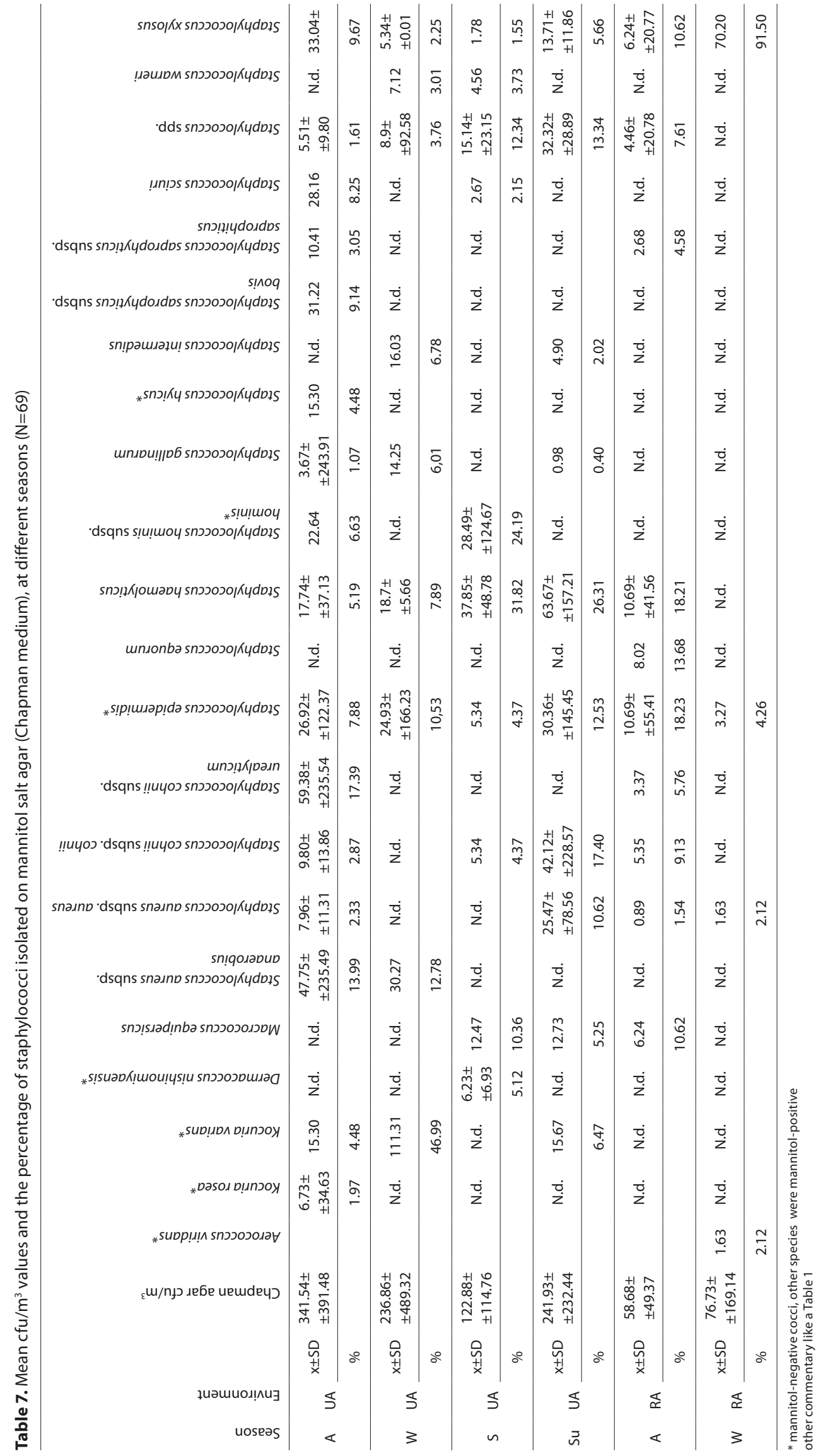


Table 8. The occurrence of Gram-positive cocci (isolated on Chapman medium) in the particular offices (1-44) across seasons

\begin{tabular}{|c|c|c|c|c|c|c|}
\hline \multirow{2}{*}{ Species } & \multicolumn{4}{|c|}{ Urban areas } & \multicolumn{2}{|c|}{ Rural areas } \\
\hline & Autumn & Summer & Spring & Winter & Autumn & Winter \\
\hline Aerococcus viridans & N.d. & N.d. & N.d. & N.d. & N.d. & 28 \\
\hline Kocuria rosea & 18,20 & N.d. & N.d. & N.d. & N.d. & N.d. \\
\hline Kocuria varians & 17 & 1 & N.d. & 32 & N.d. & N.d. \\
\hline Dermacoccus nishinomiyaensis & N.d. & N.d. & 6,8 & N.d. & N.d. & N.d. \\
\hline Staphylococcus aureus subsp. anaerobius & 4,37 & N.d. & N.d. & N.d. & N.d. & N.d. \\
\hline Staphylococcus aureus subsp. aureus & $1,3,5$ & $3,10,11$ & N.d. & N.d. & 12 & 30 \\
\hline Staphylococcus cohnii subsp. cohnii & $1,5,17$ & 7,8 & 5 & N.d. & 16 & N.d. \\
\hline Staphylococcus cohnii subsp. urealyticum & $6,20,21,37$ & N.d. & N.d. & N.d. & 7 & N.d. \\
\hline Staphylococcus epidermidis & $1,21,17$ & 1,7 & 8 & N.d. & 14,25 & 28 \\
\hline Staphylococcus haemolyticus & $2,15,22$ & $6,7,8,9$ & $1,4,5,6,8$ & $27,35,34$ & 9,11 & N.d. \\
\hline Staphylococcus gallinarum & $1,3,21$ & 11 & N.d. & 36 & N.d. & N.d. \\
\hline Staphylococcus hominis subsp. hominis & 17,20 & N.d. & 2,11 & N.d. & N.d. & N.d. \\
\hline Staphylococcus hyicus & 13 & N.d. & N.d. & N.d. & N.d. & N.d. \\
\hline Staphylococcus intermedius & N.d. & 7 & N.d. & 32 & N.d. & N.d. \\
\hline Staphylococcus saprophyticus subsp. bovis & 20 & N.d. & N.d. & N.d. & N.d. & N.d. \\
\hline Staphylococcus saprophyticus subsp. saprophyticus & 13 & N.d. & N.d. & N.d. & 11 & N.d. \\
\hline Staphylococcus sciuri & 13 & N.d. & 1,10 & N.d. & N.d. & N.d. \\
\hline Staphylococcus spp. & $4,6,24$ & $1,2,3,5,8,9$ & $4,7,9$ & $1,3,34,35$ & 10,26 & N.d. \\
\hline Staphylococcus warneri & N.d. & N.d. & 2 & 4 & N.d. & N.d. \\
\hline Staphylococcus xylosus & $2,5,18$ & $1,2,3,7,8,10$ & 11 & 1,31 & 16,19 & 29 \\
\hline
\end{tabular}

in winter than in summer. A similar relationship was found in this study, as it concerned the statistically significant differences in total bacteria concentrations between urban and rural offices in winter and summer. According to Jones [10], outdoor air is a major source of microorganisms found indoors, especially in summer and autumn. Following this statement, and assuming that urban air is characterized by higher concentrations of bacteria, compared to rural areas in the same geographical region [26], some differences in the concentrations of microflora in veterinary practices can be explained to certain extent. It should be emphasized, though, that this is not the only reason behind this phenomenon. The composition of atmospheric bioaerosol is the result of diversity of environmental sources (soil, leaf surfaces and other plant tissues, plant litter, etc.) $[27,28]$. Certain groups of bacteria show noticeable changes in their abundance in particular seasons and can be associated with a particular habitat. This variability suggests that local environmental sources play a significant role in their shaping. In own study, the genera of Arthrobacter, Cellulomonas, Microbacterium and Corynebacterium were isolated, which commonly occur in soil, water or are related to vegetation $[29,30]$. Therefore, the season itself and environmental conditions, except some other minor factors, have a significant impact on the qualitative and quantitative composition of microorganisms. The 'other factors' include the presence of humans and animals, their size and level of activity, as well as reflexes of sneezing and coughing associated with the breathing process [28]. Both the human body and animal hair create a natural habitat for a number of microorganisms which are released into the air and are deposited on the fittings and the floor.
The high content of bacteria specific for skin, nose and human hair, found in the air and the dust, indicate that the floor is an important reservoir for human bacteria which, being resuspended, have a strong influence on the structure of the microbial population in air [31].

Apart from humans, animals can be a major source of bacteria in indoor spaces, especially in those places where their congestion is considerable. Fujimura et al. [12] reported a large increase in the number and diversity of bacteria in domestic dust, of which the major part was probably transported from outside on animals' hair. This suggests why, in addition to external and seasonal factors, low levels of bacterial bioaerosol in rural veterinary offices were reported. Veterinary work in rural areas focuses rather on dealing with farm animals. Thus, visiting patients away from the clinic is more frequent, while the number of admissions of small animals (dogs, cats) is smaller, which is a result of the specific nature of the field-work as well as the resident's needs for veterinary care of accompanying animals.

Especially noteworthy are the results obtained by Harper et al. [24] who conducted a study of bacterial pollution in a small animal clinic. They observed higher concentrations of microorganisms in areas where the animals were housed on a 24-hour basis, including those that experienced intense mixing of air as a result of the opening of doors and windows, movement of personnel, and lack of regular cleaning of ventilation ducts. A smaller number of microorganisms were present in the air after cleaning. The highest levels of bacterial contamination of air ranging from $500 \mathrm{cfu} /$ $\mathrm{m}^{3}$ (in the morning) - $300 \mathrm{cfu} / \mathrm{m}^{3}$ (in the afternoon, after cleaning) were found by Harper et al. [24] in the premises 
where the animal stay was permanent - in cages and postprocedural room (observational). The concentrations in ambulatory rooms were, respectively, 50 and $200 \mathrm{cfu} / \mathrm{m}^{3}$. There were statistically significant differences in the amount of microorganisms in these rooms in the morning and in the afternoon.

For comparison, in the presented study, in areas where admissions were being made, significantly higher concentrations of the total number of bacteria ranging from $39-5,034 \mathrm{cfu} / \mathrm{m}^{3}$ were detected. Most probably a couple of factors had an impact on it: first of all, the importance of the sampling season is unquestionable (Harper et al. do not specify the time of year in which their study took place), the type of substrate used for the isolation of bacteria, the nature of the facility, the elevation at which sampling was carried out (in Harper's study it was at $1.5 \mathrm{~m}$, in the current study there were 3 different levels), and the presence or absence of air conditioning. Bacterial flora found by Harper et al. was mostly represented by numerous species of the genus Micrococcus, Staphylococcus, Corynebacterium and Bacillus, while Micrococcus and Staphylococcus were the most frequently isolated groups of bacteria. Besides, in those rooms where animals were staying at all times, the amount of Micrococcus was significantly higher than any other bacteria $(\mathrm{p}<0.05)$. The concentrations of Gram-negative bacteria in the presented study accounted for the lowest percentage of all the isolated bacteria, and were similar to the results obtained by Harper et al. [24]. The results obtained by Noris et al. [32] may provide some explanation for the similarity, as they showed that bacteria present in house dust, especially Gram-negative bacteria, are not of human origin and their occurrence is presumably due to the outside air. A minor concentration of Gram-negative bacteria in the bioaerosol of veterinary practices, compared with a higher concentration of Gram-positive, may also result from the increased resistance of Gram-positive bacteria and their ability to survive in strong sunlight $[26,33]$. Studies of the bacterial bioaerosol in veterinary practices and small animals clinics [24,25] showed significant similarity to the composition of the microflora of residential and office buildings, where Gram-positive cocci (species Micrococcus spp., Staphylococcus spp.) were the most common microorganisms. Their presence was also detected in the outside air; however, the concentration was higher indoors, prevailing in summer compared to winter [34]. The presented study indicates that veterinary clinics create habitats for many Gram-positive cocci, including pathogens opportunistic for humans and animals.

Among the species of greatest clinical significance, coagulase-positive staphylococci were isolated: Staphylococcus aureus subsp. aureus, S. aureus subsp. anaerobius and $S$. intermedius, some of which may exhibit resistance to methicillin. The methicillin-resistant S. aureus (MRSA) and methicillin-resistant $S$. pseudintermedius (MRSP) have been a problem in veterinary medicine for many years for both animals and public health. MRSA occur in clinically healthy animals, although they are often the cause of many opportunistic infections. In veterinary practice, they become an important factor of occupational risk due to constant and direct contact between the staff and animals. There are studies which have shown a similarity between human and animal strains of MRSA, which may suggest transmission between the species [35]. Also, a sharp increase in the number of nonhospital MRSA infections in healthy individuals in recent years points to other sources of these microorganisms [36]. Methicillin-resistant Staphylococcus are a major challenge for medicine, but soon it may appear that methicillin susceptible strains of S. pseudintermedius (MRSP) will become a major challenge for public health because, as shown by Paul et al. [37], they colonize humans more effectively than HMRSA.

\section{CONCLUSIONS}

1) In rural clinics, the mean number of microorganisms isolated on blood agar (in each of the separated groups) was lower compared to urban clinics.

2) Gram-positive cocci of Staphylococcus genera and Grampositive rods (Brevibacterium, Corynebacterium) were prevalent in urban clinics during summer and autumn.

3) In the examined clinics, the total concentration of bacteria was within the range of $39-5,034 \mathrm{cfu} / \mathrm{m}^{3}$, and in most cases did not exceed the proposals of acceptable concentrations for residential rooms and offices. However, the presence of pathogenic microorganisms and prolonged exposure can create a health risk for allergic symptoms in staff.

4) Studies have shown that the concentration and type/ species composition of microorganisms in the air in veterinary facilities may be correlated with external climatic conditions and habitats, as well as placement (town, village).

5) This attempt to evaluate the aerogenic microflora in a veterinary practice is the first of its kind in Poland, and one of the few in the world. It is therefore appropriate to conduct further research and incorporate air quality monitoring for current assessment of the exposure to potentially pathogenic microorganisms.

\section{REFERENCES}

1. Scheftel JM, Elchos BL, Cherry B, DeBess EE, Hopkins SG, Levine JF, Williams CJ, Bell MR, Dvorak GD, Funk RH, Just SD, Samples OM, Schaefer EC, Silvia CA. Compendium of Veterinary Standard Precautions for Zoonotic Disease Prevention in Veterinary Personnel: National Association of State Public Health Veterinarians Veterinary Infection Control Committee. JAVMA. 2010; 237(12): 1403-1422.

2. PN-N-18002:2000 Systemy zarządzania bezpieczeństwem i higieną pracy. Ogólne wytyczne do oceny ryzyka zawodowego (in Polish).

3. CDC/National Institutes of Health. Biosafety in microbiological and biomedical laboratories. 5th ed., 2009.

4. Elchos B, Scheftel J, Cherry B, DeBess E, Hopkins S, Hunter L, Levine J, Williams C. Compendium of veterinary standard precautions: zoonotic disease prevention in veterinary personnel. National Association of State Public Health Veterinarians, Veterinary Infection Control Committee 2006.

5. Douwes J, Thorne P, Pearce N, Heederik D. Bioaerosol health effects and exposure assessment: progress and prospect. Ann Occup Hyg. 2003; 47(3): 187-200.

6. Srikanth P, Sudharsanam S, Steinberg R. Bio-aerosols in indoor environment: composition, health effects and analysis. Indian J Med Microbiol. 2008; 26(4): 302-312.

7. Development of WHO guidelines for indoor air quality. Report on a working group meeting; Oct 23-24 2006; Bonn, Germany.

8. Górny RL. Biologiczne czynniki szkodliwe: Normy, zalecenia i propozycje wartości dopuszczalnych. Podstawy i Metody Oceny Środowiska Pracy. 2004; 3(41): 17-39 (in Polish).

9. Dutkiewicz J, Śpiewak R, Jabłoński L, Szymańska J. Biologiczne czynniki zagrożenia zawodowego. Klasyfikacja, narażone grupy zawodowe, pomiary, profilaktyka. Ad punctum, Lublin 2007 (in Polish).

10. Jones AP. Indoor air quality and health. Atmos Environ. 1999; 33(28): 4535-4564. 
11. Montanaro A. Indoor allergens: description and assessment of health risks. In: Bardana EJ, Montanaro A (eds.). Indoor air pollution and health. Marcel Dekker, New York 1997, pp. 201-214.

12. Fujimura KE, Johnson CC, Ownby DR, Cox MJ, Brodie EL, Havstad SL, Zoratti EM, Woodcroft KJ, Bobbitt KR, Wegienka G, Boushey HA, Lynch SV. Man's best friend? The effect of pet ownership on house dust microbial communities. J Allergy Clin Immunol. 2010; 126(2): 410-412.

13. Noris F, Siegel JA, Kinney KA. Evaluation of HVAC filters as a sampling mechanism for indoor microbial communities. Atmos Environ. 2011; 45(2): $338-346$

14. Occupational health and safety for veterinary medical units program guide. Program Guide 10-05, M-3, Part I. Department of Veterans Affairs, Veterans Health Administration, Research and Development; Mar 6; Washington, USA 1996.

15. Dutkiewicz J, Pomorski ZJH, Sitkowska J, Krysińska-Traczyk E, Skórska C, Prażmo Z, Cholewa G, Wójtowicz H. Airborne microorganisms and endotoxin in animal house. Grana. 1994; 33(2): 85-90.

16. Chang CW, Chung H, Huang CF, Su HJ. Exposure of workers to air borne microorganisms in open-air swine houses. Appl Environ Microbiol. 2001; 67(1): 155-161.

17. Chmielowiec-Korzeniowska A, Tymczyna L, Skórska C, Sitkowska J, Cholewa G, Dutkiewicz J. Efficacy of a novel biofilter in hatchery sanitation: I. Removal of airborne bacteria, dust and endotoxin. Ann Agric Environ Med. 2007; 14: 141-150.

18. Nehme B, Létourneau V, Forster RJ, Veillette M, Duchaine C. Cultureindependent approach of the bacterial bioaerosol diversity in the standard swine confinement buildings, and assessment of the seasonal effect. Environ Microbiol. 2008; 10(3): 665-675.

19. Samadi S, Wouters IM, Houben R, Jamshidifard AR, Van Eerdenburg F, Heederik DJ. Exposure to inhalable dust, endotoxins, beta(1->3)glucans, and airborne microorganisms in horse stables. Ann Occup Hyg. 2009; 53(6): 595-603.

20. Szadkowska-Stańczyk I, Bródka K, Buczyńska A, Cyprowski M, Kozajda A, Sowiak M. Exposure to bioaerosols among CAFO workers (swine feeding). Med Pr. 2010; 61(3): 257-269.

21. Samadi S, Wouters IM, Dick JJ, Heederik DJJ. A review of bio-aerosol exposures and associated health effects in veterinary practice. Ann Agric Environ Med. 2013; 20(2): 206-221.

22. Krogulski A. Metody oznaczania ogólnej liczby bakterii w powietrzu atmosferycznym i wewnątrz pomieszczeń. Roczn PZH. 2006; 57(1): 1-7 (in Polish).

23. Górny RL, Dutkiewicz J. Bacterial and fungal aerosols in indoor environment in Central and Eastern European countries. Ann Agric Environ Med. 2002; 9: 17-23.

24. Harper TAM, Bridgewater S, Brown L, Pow-Brown P, Stewart-Johnson A, Adesiyun AA. Bioaerosol sampling for airborne bacteria in a small animal veterinary teaching hospital. Infect Ecol Epidemiol. 2013; 3 20376 - http://dx.doi.org/10.3402/iee.v3i0.20376.

25. Jo W-K, Kang J-H. Workplace exposure to bioaerosols in pet shops, pet clinics, and flower garden. Chemosphere. 2006; 65(10): 1755-1761.

26. Fahlgren C, Hagström A, Nilsson D, Zweifel UL. Annual variations in the diversity, viability, and origin of airborne bacteria. Appl Environ Microbiol. 2010; 76 (9): 3015-3025.

27. Bowers RM, McCubbin IB, Hallar AG, Fierer N. Seasonal variability in airborne bacterial communities at a high-elevation site. Atmos Environ. 2012; 50: 41-49.

28. Pitkäranta M. Molecular profiling of indoor microbial communities in moisture damaged and non-damaged buildings. Doctoral dissertation (article-based). University of Helsinki, Faculty of Biological and Environmental Sciences, Department of Biosciences, Division of General Microbiology. 2012; 1-84 - http://urn.fi/ URN:ISBN:978-952-10-7569-8.

29. Bernard K. The genus Corynebacterium and other medically relevant coryneform-like bacteria. J Clin Microbiol. 2012; 50(10): 3152-3158.

30. Funke G, Pagano-Niederer M, Sjödén B, Falsen E. Characteristics of Arthrobacter cumminsii, frequently the most encountered Arthrobacter species in human clinical specimens. J Clin Microbiol. 1998; 36(6): 1539-1543.

31. Hospodsky D, Qian J, Nazaroff WW, Yamamoto N, Bibby K, RismaniYazdi H, Peccia J. Human occupancy as a source of indoor airborne bacteria. PLoS One. 2012; 7(4): e34867.

32. Noris F, Siegel JA, Kinney KA. Evaluation of HVAC filters as a sampling mechanism for indoor microbial communities. Atmos Environ. 2011; 45: 338-346.

33. Xie S, Hong J, Wang D, Guan M, Yao R, Liang S, Liu H, Jiang R, Zhang Y. The composition of atmosphere microorganisms (in Chinese). J Environ Sci. 1988; 1: 39-47.

34. Tang JW. The effect of environmental parameters on the survival of airborne infectious agents. J R Soc Interface. 2009; 6: 737-746.

35. Weese JS, van Duijkeren E. Methicillin-resistant Staphylococcus aureus and Staphylococcus pseudintermedius in veterinary medicine. Vet Microbiol. 2010; 140(3-4): 418-429.

36. Rintala H, Pitkäranta M, Toivola M, Paulin L, Nevalainen A. Diversity and seasonal dynamics of bacterial community in indoor environment. BMC Microbiol. 2008; 8: 56 - http://www.biomedcentral.com/14712180/8/56.

37. Paul NC, Moodley A, Ghibaudo G, Guardabassi L. Carriage of methicillin-resistant Staphylococcus pseudintermedius in small animal veterinarians: indirect evidence of zoonotic transmission. Zoonoses PublicHLTH. 2011; 58(8): 533-539. 